\title{
New Ediacaran fossils from the Ukraine, some with a putative tunicate relationship
}

\author{
Andrej Martyshyn ${ }^{1}$ (D) Alfred Uchman ${ }^{2}$ (i)
}

Received: 16 February 2021 / Accepted: 22 November 2021 / Published online: 8 December 2021

(c) The Author(s) 2021

\begin{abstract}
Sack-like body fossils Finkoella ukrainica gen. et sp. nov. and F. oblonga sp. nov., and reticulate fossil Pharyngomorpha reticulata gen. et sp. nov. are described from the upper Ediacaran shallow-marine deposits of Ukraine, which are no younger than $557 \mathrm{Ma}$. The first two resemble the flattened bodies of tunicates showing mainly the outline of tunica, while the third is considered as a fragment of the pharyngeal basket of a tunicate. $F$. ukrainica is represented by smaller individuals interpreted as juveniles, which may occur in clusters together with less numerous larger individuals. The larger forms are interpreted as adults, some of which show the preserved oral/atrial syphons and possible traces of internal organs bulging through the tunica. Moreover, Burykhia sp. from the uppermost Ediacaran of the same region is presented. This is the second and younger occurrence of the genus Burykhia, which is preserved as a possible fragment of the pharyngeal basket. All the fossils are preserved as the "death masks" between microbial mats, and their appearance depends partly on the relation to the parting surface on which they are observed. The presented new taxa along with the literature data reinforce the possibility that tunicates originated already in late Ediacaran.
\end{abstract}

Keywords Vendian $\cdot$ Precambrian $\cdot$ Tunicata $\cdot$ Ascidiacea $\cdot$ East European Platform

\section{Introduction}

In the recent marine environments, the Ascidiacean tunicates (Tunicata: Ascidiacea) are world-widespread and diverse (2815 species) filter-feeding, mostly sessile, colonial or solitary invertebrates having sack-like body and two syphons. They are important link in the phylogenetic tree because they are regarded as the ancestors of chordates (Lambert 2005; Shenkar and Swalla 2011; Holland 2016). Their unquestionable fossils are dated back to the early Cambrian, as exemplified by Shankouclava shankouense Chen et al., 2003 from

Handling Editor: Joachim Reitner.

Alfred Uchman

alfred.uchman@uj.edu.pl

Andrej Martyshyn

podolimirus@gmail.com

1 Institute of Geology, Taras Shevchenko National University of Kyiv, 90 Vasylkivska Str, Kyiv 03022, Ukraine

2 Faculty of Geography and Geology, Institute of Geological Sciences, Jagiellonian University, Gronostajowa 3a, 30-387 Kraków, Poland
China. However, three taxa considered as ascidiaceans are known from the upper Ediacaran, i.e. Ausia fenestrata Hahn and Pflug, 1985 from the Kuibis Quartzite (549-543 Ma) of the Nama Group in Namibia, poorly preserved Yarnemia acidiformis Nessov in Chistyakov et al., 1984 from the Ediacaran in the middle reaches of the Onega river (lower part of the Erginskaya Formation (550-552 Ma; see Grazhdankin 2011; Grazhdankin and Maslov 2015), and Burykhia hunti Fedonkin et al., 2012 from the Ediacaran beds (Verkhovka Formation, $555 \mathrm{Ma}$ ), both in the White Sea coast region in the north-western Russia. Ausia is known from one specimen, and Burykhia from two specimens.

In this paper, four new fossil taxa which could be ascidiacean tunicates are presented from the Ediacaran of Podolia in Ukraine (Fig. 1). One of them is represented by several specimens. These fossils add a new information to the discussion on the still poorly recognized early evolution of the class Ascidiacea. The rocks bearing them are no younger than $557 \mathrm{Ma}$. Therefore, the fossils are potentially the possible oldest representatives of tunicates if their systematic position is so. The Ediacaran of Podolia provided several taxa of macrofossils belonging to diverse taxonomic groups (e.g., Palij 1976; Fedonkin 1985; Velikanov 1985; Fedonkin 


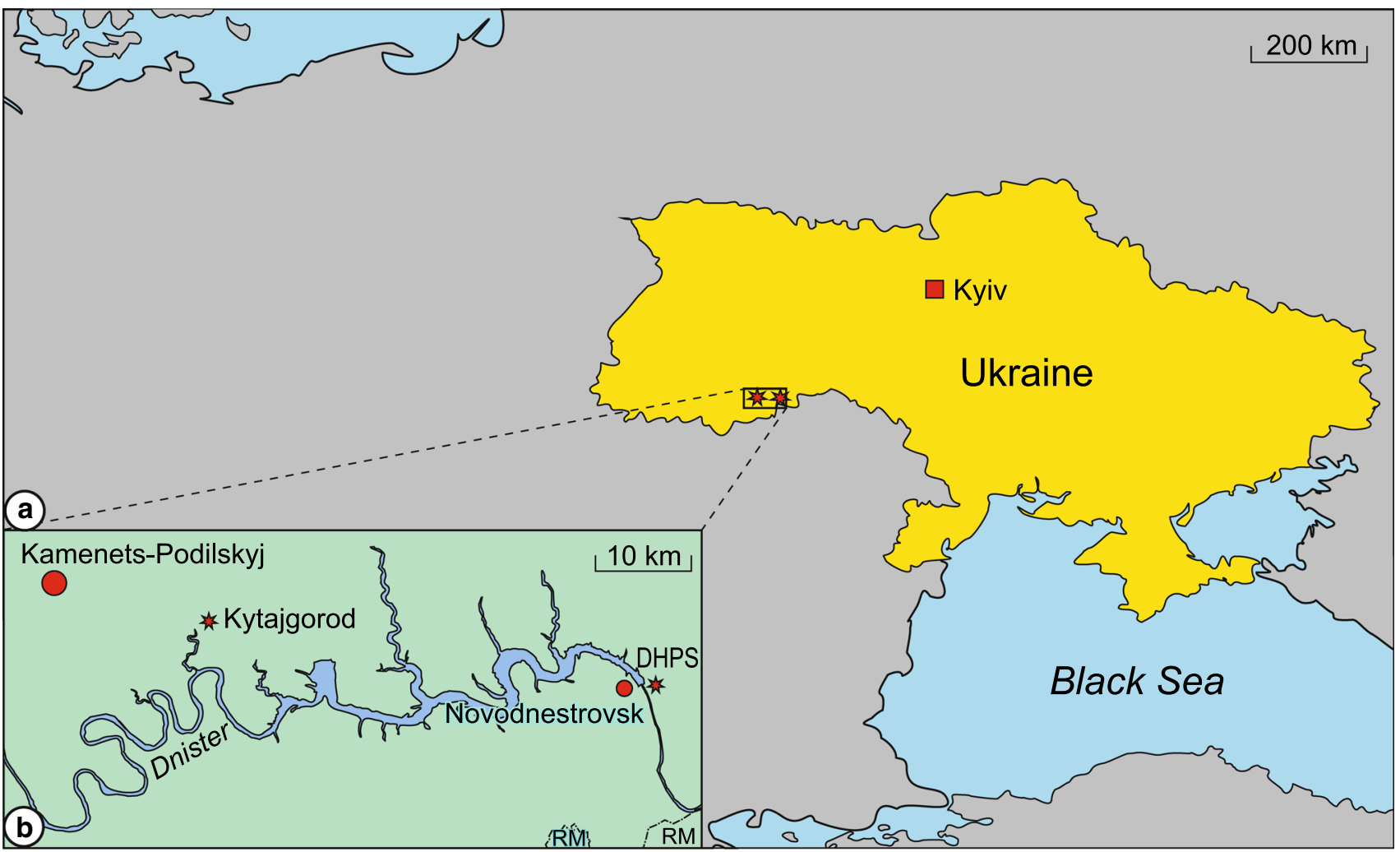

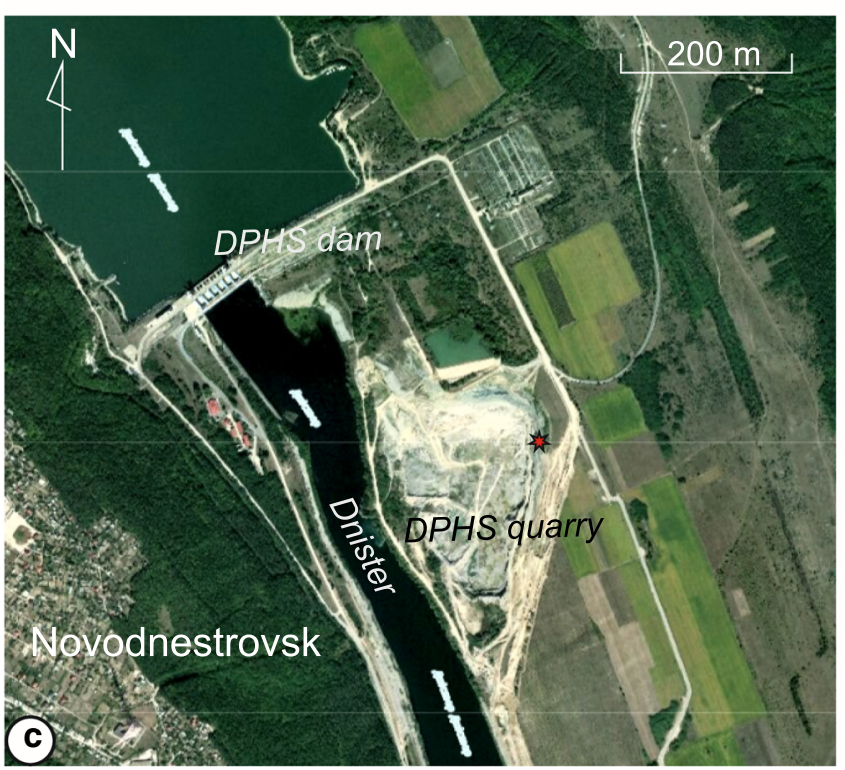

Fig. 1 Location maps. a Location of the study region. b Study region with indication of the studied sections. c Location of the upper Ediacaran section (star) near the Dniester hydroelectric dam (DPHS);

and Vickers-Rich 2007; Martyshyn 2012; Gozhik 2013; Ivantsov et al. 2015; Dzik and Martyshyn 2015, 2017; Nesterovsky et al. 2018; Soldatenko et al. 2019). Moreover, some ichnotaxa are described from these deposits (e.g., Palij 1974, 1976; Gureev 1983, 1984, 1986; Ivantsov et al. 2015; Grytsenko 2020; Uchman and Martyshyn 2020).

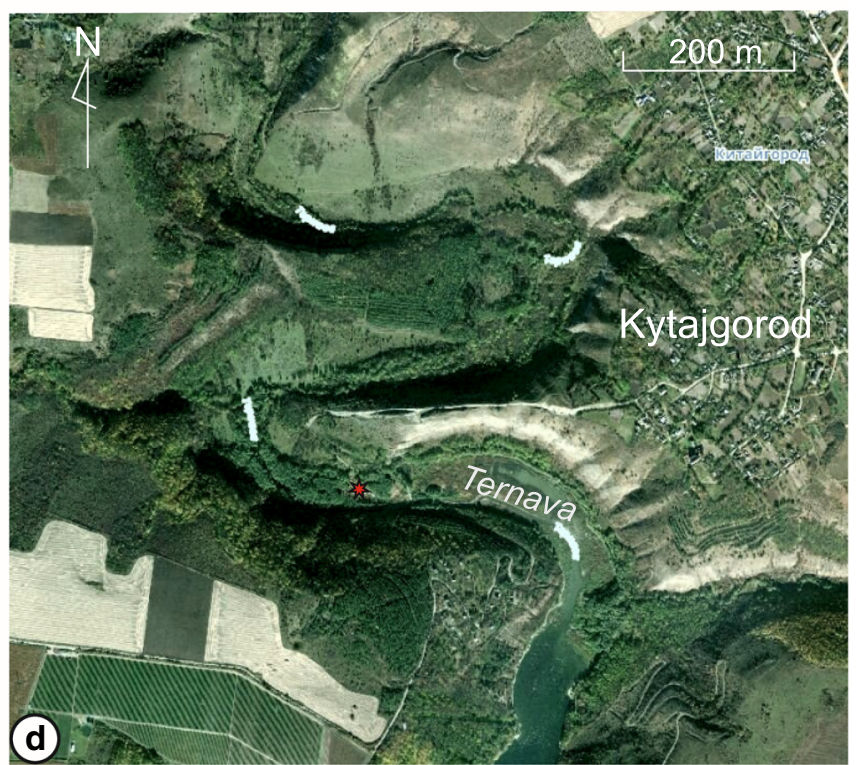

based on Google Maps. d Location of the uppermost Ediacaran section (star) of the Studenitsa Formation at Kitaygorod; based on Google Maps

\section{Geological setting}

The study area stretches on the southwest flank of the Ukrainian Shield, which is called the Volyn-PodillyaMoldavia Basin. During the Ediacaran Period, the basin 
developed as a rifted, passive continental margin in the tectonic extension regime (Poprawa et al. 2018). The Ediacaran deposits belong to the Volyn (Volhynia), MogilevPodolsky (Mohyliv-Podilsky) and the Kanilovka (Kanyliv) groups. The Mogilev-Podolsky Group contains the Mogilev Formation (Mogilev Series in the Russian literature) in the lower part. Almost all the studied fossils derive from the Mogilev Formation, except for Burykhia sp., which derives from the Studenitsa Formation at the top of the Kanilovka Group (Fig. 2).

Fossils from the Mogilev Formation were collected from the Novodnistrovs'k Quarry (Fig. 1c), which was monitored since 20 years by the senior author (Martyshyn 2012). At the bottom of the quarry, Lower Proterozoic granites and migmatites of the Ukrainian Shield are exposed. They are blanked by thin (up to a metre), discontinuous layer of basal conglomerates, which underlie the Lomozov (Lomoziv) Member of the Mogilev Formation. This member is dominated by mudstones and siltstones, which represent the second sedimentary cycle in the Podolia Ediacaran (Korenchuk and Ishchenko 1981). Some specimens of Finkoella oblonga, Pharyngomorpha reticulata and F. ukrainica derive from this unit. The Lomozov Member contains rare dickinsoniids (Dzik and Martyshyn 2015) and relatively common disc-like representatives of the Petalonamae group (Dzik and Martyshyn 2017). A higher position is occupied by the Yampol (Yampil) Member, which is composed of thick and very thick, partly cross-bedded sandstones (up to $9 \mathrm{~m}$ thick) and a package of thin sandstone and siltstone beds (up to $3 \mathrm{~m}$ thick) at the top. The holotype and paratype of Finkoella ukrainica presented in this paper derive from the top part of the Yampol Member. The overlying Lyadova (Lyadov) Member crowns the Mogilev Formation. It consists up to $2 \mathrm{~m}$-thick siltstone at the base followed by up to $14 \mathrm{~m}$-thick mudstone with intercalations of thin siltstone or sandstone beds.

The base of the overlying Yaryshev (Yarishiv) Formation was previously dated to 553 Ma by Grazhdankin et al. (2011) and Grazhdankin (2014) but newer dating of bentonite layers from the Yampol Member top package (layer B1, c. $1 \mathrm{~m}$ above the thick-bedded sandstones) points to $556.78 \pm 0.18 \mathrm{Ma}$ (Soldatenko et al. 2019). The presented fossils from the upper part of the Yampol Member are below the bentonite. Therefore, all the presented fossils are no younger than roughly $557 \mathrm{Ma}$.

Burykhia was found in a small abandoned quarry in the Ternava river gorge near Kitaygorod in the Khmelnytsky region (Fig. 1d), where the Komarovo Member form the uppermost part of the Studenitsa Formation $(60 \mathrm{~m}$ thick) which is located in the uppermost part top of the Kanilovka Group. The Komarovo Member are composed of rhythmic intercalations of laminated mudstones and siltstones, which are intercalated with occasional sandstone beds. This formation transits up to the lower part of the Okunets Formation of the Baltic Group, which is already considered as the lower Cambrian (Cambrian Series 1) containing the trace fossil Treptichnus pedum (Seilacher, 1955) (see Ivantsov et al. 2015). Beside this and other trace fossils, the Studenitsa Formation contains body fossils of algae, including Tyrasotaenia podolica Gnilovskaya, 1971, Vendotaenia antiqua Gnilovskaja, 1971 (Ivantsov et al. 2015), Tymkivia stuzhuki Martyshyn in Nestrovsky et al., 2018, the protozoan or alga Harlaniella vermiformis Martyshyn in Nesterovsky et al., 2018, and the protozoan Palaeopascichnus delicatus Palij, 1976 (Nesterovsky et al. 2018).

\section{Materials}

The presented specimens are collected by (1) A. Martyshyn in collaboration with a research group during 20 years of the field work and monitoring of the quarry near the Dniester hydroelectric dam (DPHS) and other outcrops (Fig. 1), and by (2) S. Finko who provided the holotype of $F$. ukrainica and the large sandstone slab with the paratype of F. ukrainica material for research. Specimens of the described taxa are in the collection of the Institute of Geology of the Taras Shevchenko National University of Kyiv. They have the institutional abbreviation IGKNU.

\section{Systematic description}

\section{Subphylum Tunicata Lamarck, 1816}

Class Ascidiacea de Blainville, 1824

Remarks. Classification of the fossil Ascidiacea is based on (1) their pouch-like structure, which is similar to recent representatives of this class, (2) the presence of traces of siphons, and (3) imprints of internal organs on the surface of semi-decomposed remains, which are similar to the tunic, pharyngeal basket mantle (branchial sac), atrium, stomach, and the atrial/oral siphons of the present-day tunicates. These morphological features are typical of the family Ascidiidae Herdman, 1882 (Herdman 1882; Fedonkin et al. 2012) and cannot be misled for other group of organisms.

Genus Finkoella gen. nov. Martyshyn

Etymology. After S.V. Finko, an amateur palaeontologist, who provided the holotype and paratype of the type species.

Type species. Finkoella ukrainica sp. nov. Martyshyn. 


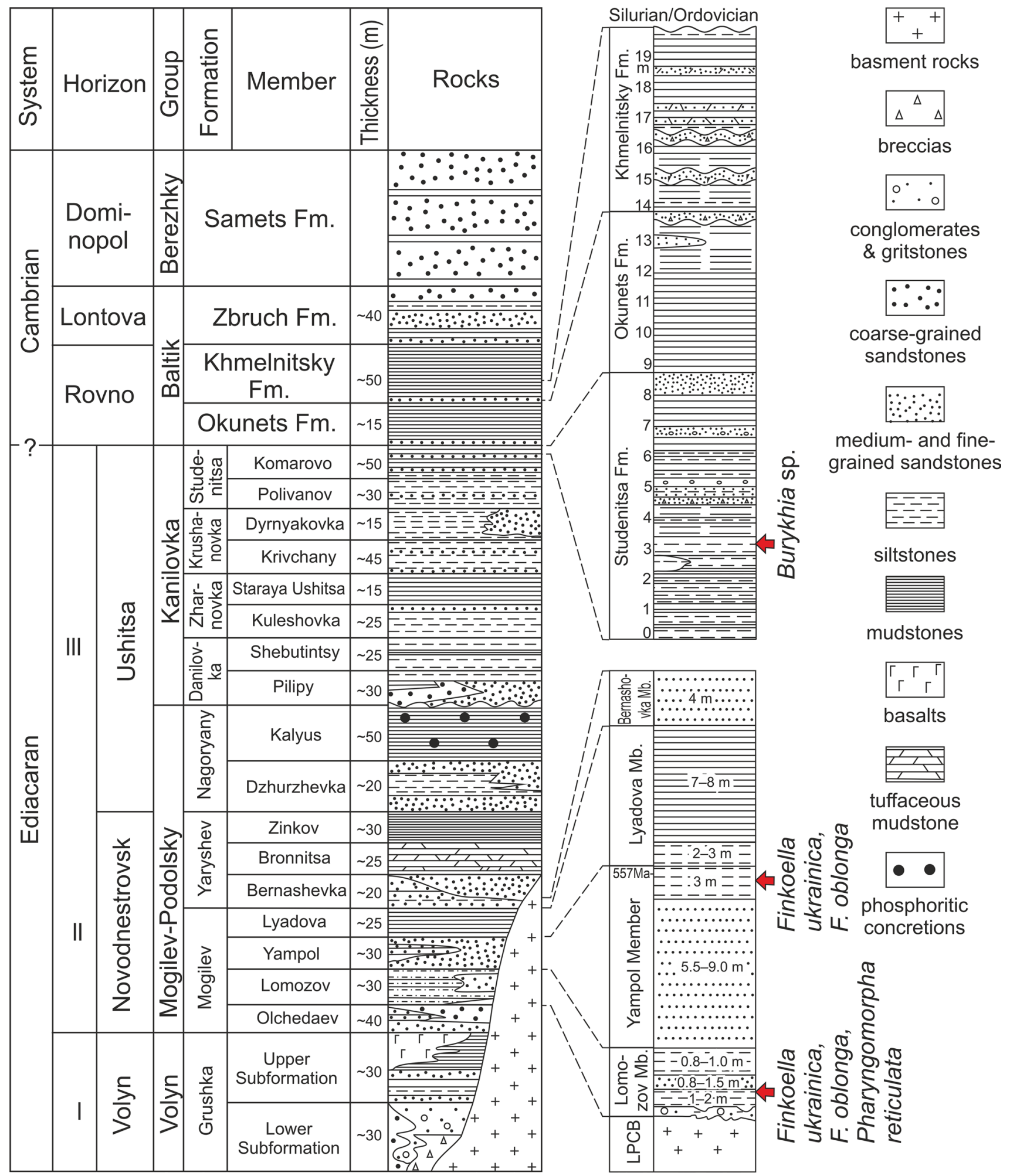

Fig. 2 Stratigraphic scheme of the Ediacaran in Podolia with inserts of the analyzed part the sedimentary succession. Stratigraphic position of described fossils indicated (based on Ivantsov et al. 2015, and references therein, modified) 
Diagnosis. A convex or concave, ovate, oval, or rarely oblong, cucumber-shaped, lenticular structure on the lower or upper surface of sandstone/siltstone/mudstone layers. In most specimens, one end is more elongated, and the opposite one is more rounded or almost even. One of the ends may show a protruded, short neck and/or a shallow sinus. A low/ shallow circular protrusion/depression can be present in the convex or concave structure, respectively. The protrusion/ depression is usually located eccentrically towards one of the ends. Moreover, some shallow/low concavities/convexities may occur on the surface. The edges are usually slightly elevated in convex specimens or depressed in concave forms.

Species. Finkoella ukrainica and F. oblonga described in this paper.

Comparison. No analogues among the Ediacaran and younger fossils.

Distribution. Lomozov and Yampol members, Mogilev Formation, Mogilev-Podolsky Group, upper Ediacaran.
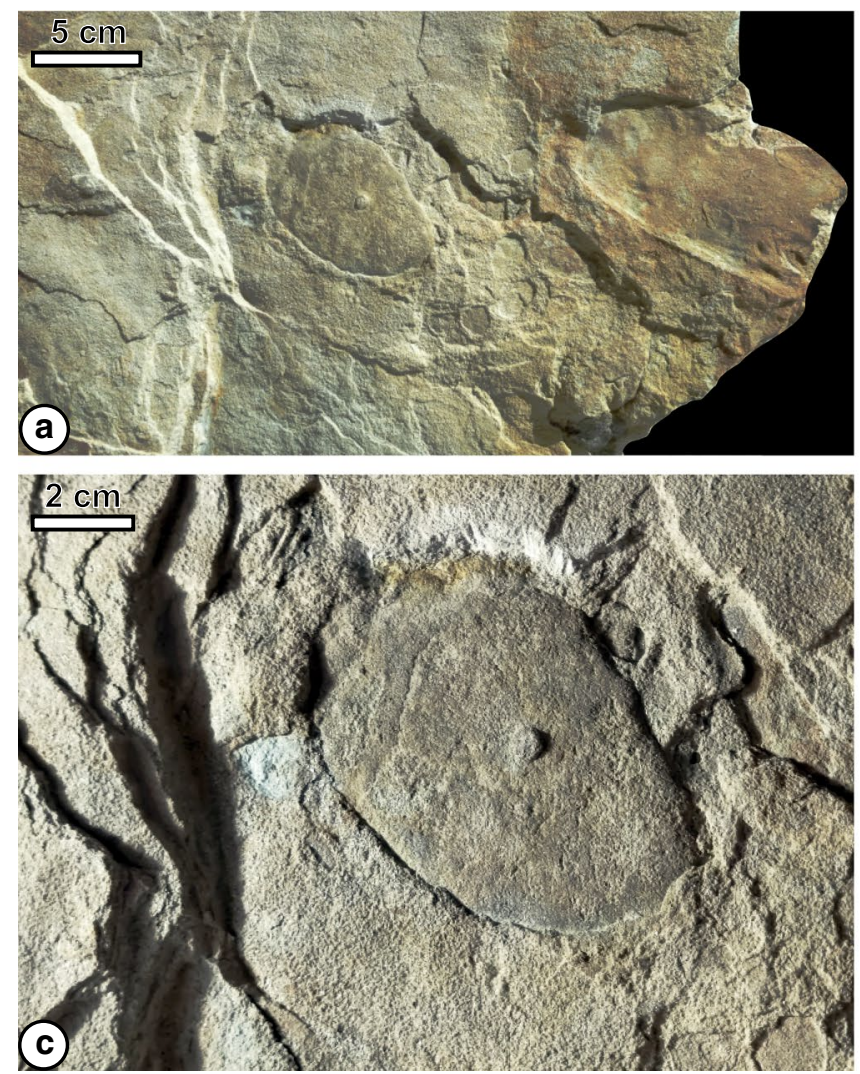

Fig. 3 Types of Finkoella ukrainica Martyshyn sp. nov. from the Yampol Member of the Mogilev Formation (upper Ediacaran) in the quarry near the DHPS, $b g$ bulge, ee elevated edge, $d m r$ double marginal ridge. a, b Lower surface of slab IGKNU17p170 showing the holotype (IGKNU17p170/1), specimen IGKNU17p170/2),
Finkoella ukrainica sp. nov. Martyshyn

Figures 3a-d, 4a-b, 5a-i, 6a-f, 7

v 2018 problematic organism, probably Tunicata.-Nesterovsky et al.: fig. $4 \mathrm{c}$.

Etymology. After the country Ukraine.

Diagnosis. Finkoella showing oval to elliptical, rarely oblong shape, which may show a protruded, short neck and/or a shallow sinus. A low/shallow circular protrusion/ depression can be present in the convex or concave structure, respectively. Smaller specimens can be without neck and protrusions/depressions.

Holotype. One of two larger structures (Figs. 3a, b) on the lower surface of the slab IGKNU17p170, i.e. the specimen IGKNU17p170/1 (Fig. 3c). The slab is built of muddy, very fine-grained sandstone and derives from the upper part of the Yampol Member of the Mogilev Formation,
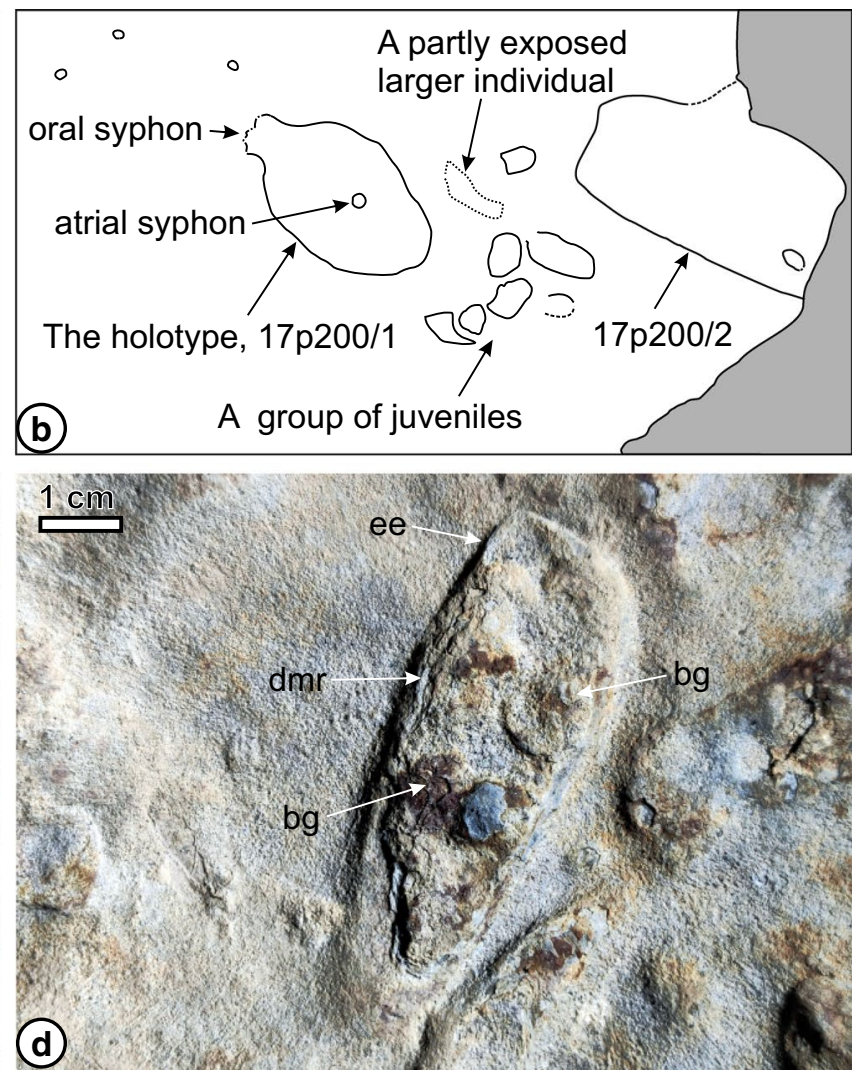

and a group of smaller specimens between them considered as juveniles. Very fine grained muddy sandstone, Yampol Member of the Mogilev Formation. c Close view of the holotype. d The paratype IGKNU17p201/1, upper surface of sandstone slab, Yampol Member of the Mogilev Formation 

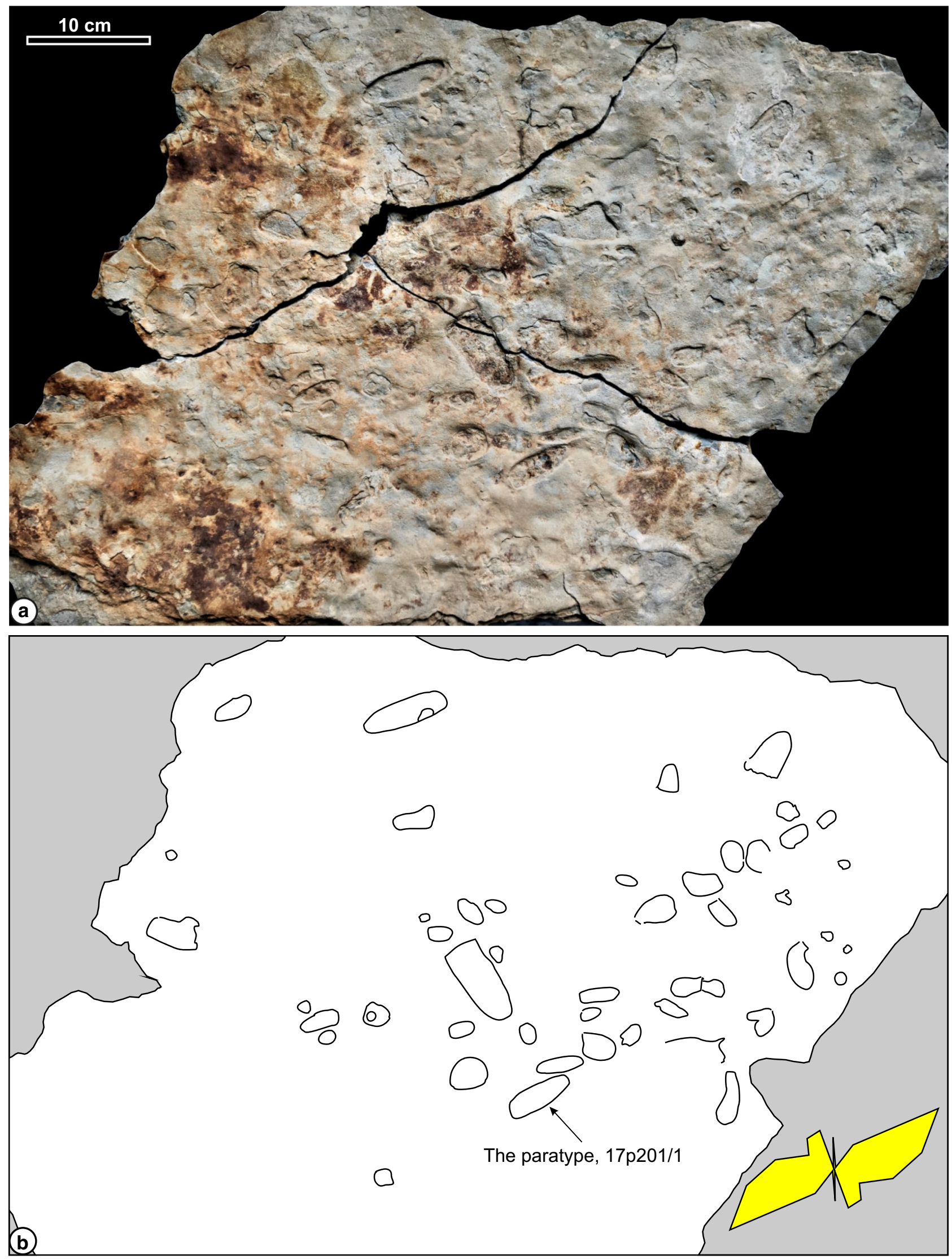
4Fig. 4 Upper surface of a large fine-grained sandstone slab IGKNU17p202 from the Yampol Member of the Mogilev Formation in the quarry near the DHPS. a General view showing several specimens Finkoella ukrainica, including the paratype. b Schematic drawing of a. Rosette in the right lower corner shows orientation of the longer axis in 31 specimens on the slab

Mogilev-Podolsky Group, in the quarry near the DHPS at Bernashivka village, Vinnytsia region.

Other materials. (1) paratype IG KNU17p201/1 (Figs. 3d, $4 \mathrm{a}, \mathrm{b}$ ) and all other (at least 46) specimens on the upper surface of sandstone slab from the upper part of the Yampol Member (Figs. 4a, b, 5); moreover (2) two specimens in slabs IGKNU17p204 (Fig. 7a), IGKNU17p210 (Fig. 7f), IGKNU17p2011 (Fig. 7g), and IGKNU 17p214 (Fig. 7j), and single specimens in slabs IGKNU17p205 (Fig. 7d), IGKNU17p207 (Fig. 7e), IGKNU17p209 (Fig. 7b), IGKNU17p208 (Fig. 7c), and IGKNU17p213 (Fig. 7i), all from the Lomozov Member of the Mogilev Formation in the quarry near the DHPS at Bernashivka village, Vinnytsia region.

Description. The holotype (Fig. 3a-c) is a convex oval structure on the lower surface of a thin bed of micaceous, clayey, very fine-grained sandstone. It is $95 \mathrm{~mm}$ long and up to $55 \mathrm{~mm}$ wide. A round protrusion, $5 \mathrm{~mm}$ in diameter, is located slightly eccentrically towards one of the ends. One of the ends is more elongated, and the opposite one is more rounded. The more rounded end shows a protruded short neck, which is wider at its termination. The termination is unevenly lobate. The margins are sharp and even. The surface of the structure is generally smooth, except for local grain-size corrugations, thin and short grooves and a longer, narrow, shallow groove which runs obliquely through three quarters of the width close to the wider end.

The second fossil is located on the same side of the slab bearing the holotype (Fig. 3a, b). This is a concave, smooth structure in the shape of a simple cucumber. One end of the structure shows a sinus, which is $4 \mathrm{~mm}$ deep and $7 \mathrm{~mm}$ wide. The opposite end is broken on the edge of the slab and therefore not available. The preserved margins are sharp and locally elevated.

The paratype (Figs. 3d, 4a, b) is a concave, elongate oval structure on the upper surface of a sandstone slab. It is $56 \mathrm{~mm}$ long and up to $25 \mathrm{~mm}$ wide. The wider end is tapered and the opposite, narrower end shows a short, indistinct neck. The surface is covered with local bulges of oval outline and irregular, gentle depressions. The structure is mostly sharply bounded along its margin, but locally the boundary is less distinct. From one side, the margin is elevated and locally marked by a double ridge, which is $2 \mathrm{~mm}$ wide (Fig. 3d). The ridge is separated by an uneven narrow groove.

Other specimens (Figs. 4, 5, 6) are usually oval, convex or concave structures; some are obtuse from one end. They show variable sizes, with length ranging from 5 to $110 \mathrm{~mm}$ and width from 5 to $55 \mathrm{~mm}$. The width versus length of all specimens show strong positive correlation ( $r=0.84$; Fig. 8). Most of the smaller specimens are usually smooth, without any neck and protrusions, but some of them show slightly elevated/depressed edges and or bulges interpreted as atrial siphon. Only some of them show a short neck (Fig. 7c) interpreted as oral siphon and knob-like protrusions/depressions. One of them shows a narrow side neck, which can be atrial syphon (Fig. 7i).

The described structures may occur in clusters (Figs. 3a, b, $4 \mathrm{a}, \mathrm{b})$. Individuals in the cluster may show different size. Longer axis of the fossil shows distinct orientation (rosette in Fig. 4b).

Remarks. The small specimens, which are less than $25 \mathrm{~mm}$ wide (see Fig. 8), are considered as representing juvenile organisms (see "Discussion"). The holotype was selected from specimens representing large, fully developed and most completely preserved organism (Fig. 9).

Finkoella oblonga sp. nov.

Figures 10

Etymology. After oblongus (Latin)—elongate, in correspondence to the overall shape.

Diagnosis. Elongated Finkoella showing winding margins and longitudinal furrows/ridges, which tend to run parallel to the margin.

Holotype. Split slab of horizontally to wavy laminated siltstone showing positive, i.e. convex fossil (IGKNU17p202/1) and is counterpart showing negative, i.e. concave part (IGKNU17p202/2). This is the only specimens of the species. It derives from the Lomozov Member of the Mogilev Formation, Mogilev-Podolsky Group, in the quarry near the DHPS at Bernashivka village, Vinnytsia region.

Other material. A split slab with specimen IGKNU17p215 and its counterpart IGKNU17p215/1, Yampol Member (Fig. 10b). Moreover, IGKNU17p216, Lomozov Member (determined as Finkoella cf. oblonga).

Description. The holotype (Fig. 10a) is an elongate, cucumber-like structure, $120 \mathrm{~mm}$ long and up to $42 \mathrm{~mm}$ wide, which is visible as a positive (convex) part and its negative (concave) counterpart in a horizontally split slab. It shows six longitudinal, low groves and ridges, which show gentle 

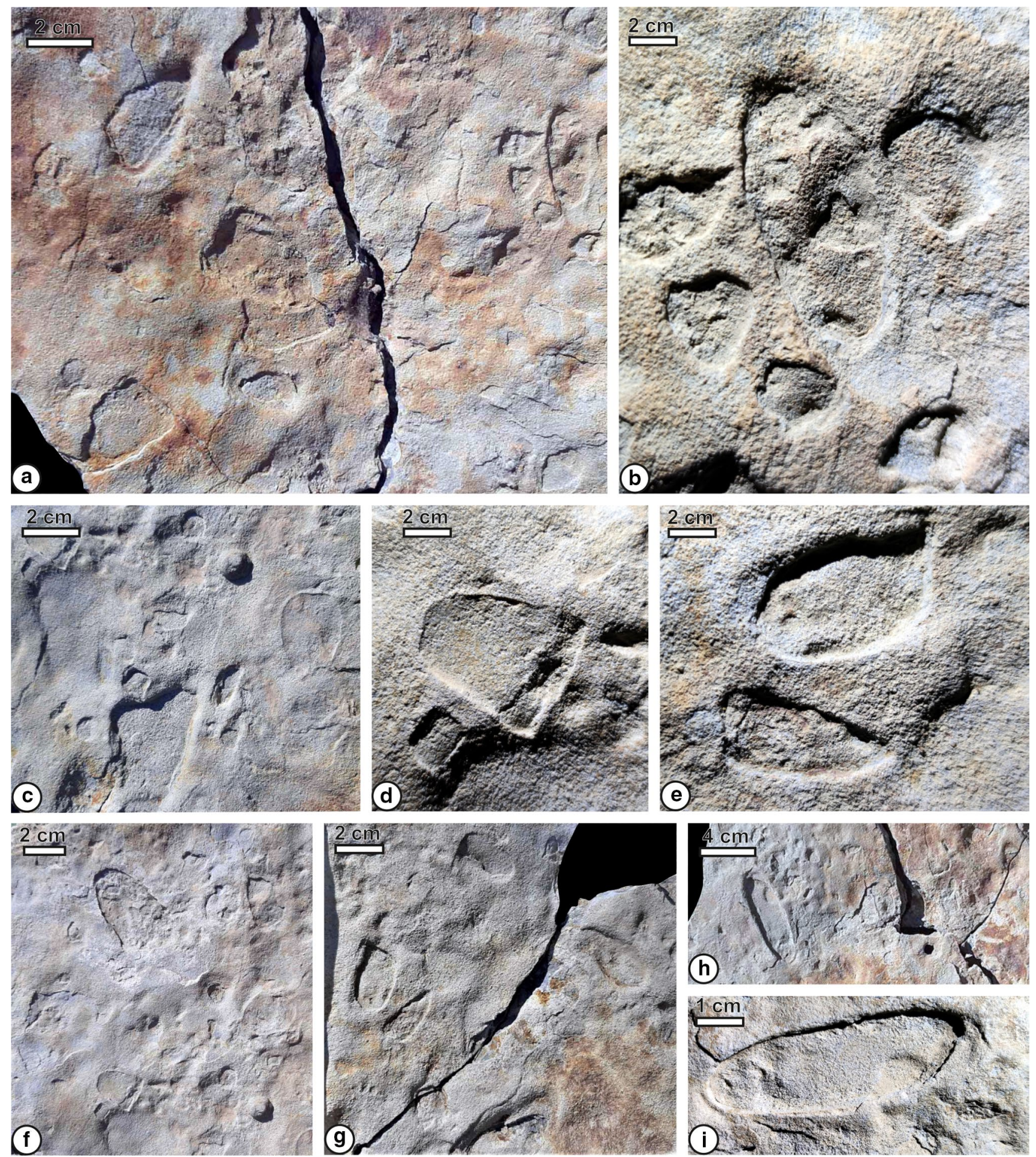

Fig. 5 Details of the large slab from Fig. 4

slopes and are 3-4 mm wide. They run parallel to the margin of the structure and turn accordingly at the terminations, so they tend to form concentring rings. They are more continuous on one side than on the other side, where only their fragments are visible. Moreover, the structure shows small corrugations, but without any pattern. Edges of the structure are distinctly elevated/depressed and locally show a double ridge or groove, which is $1.5-3 \mathrm{~mm}$ wide. 

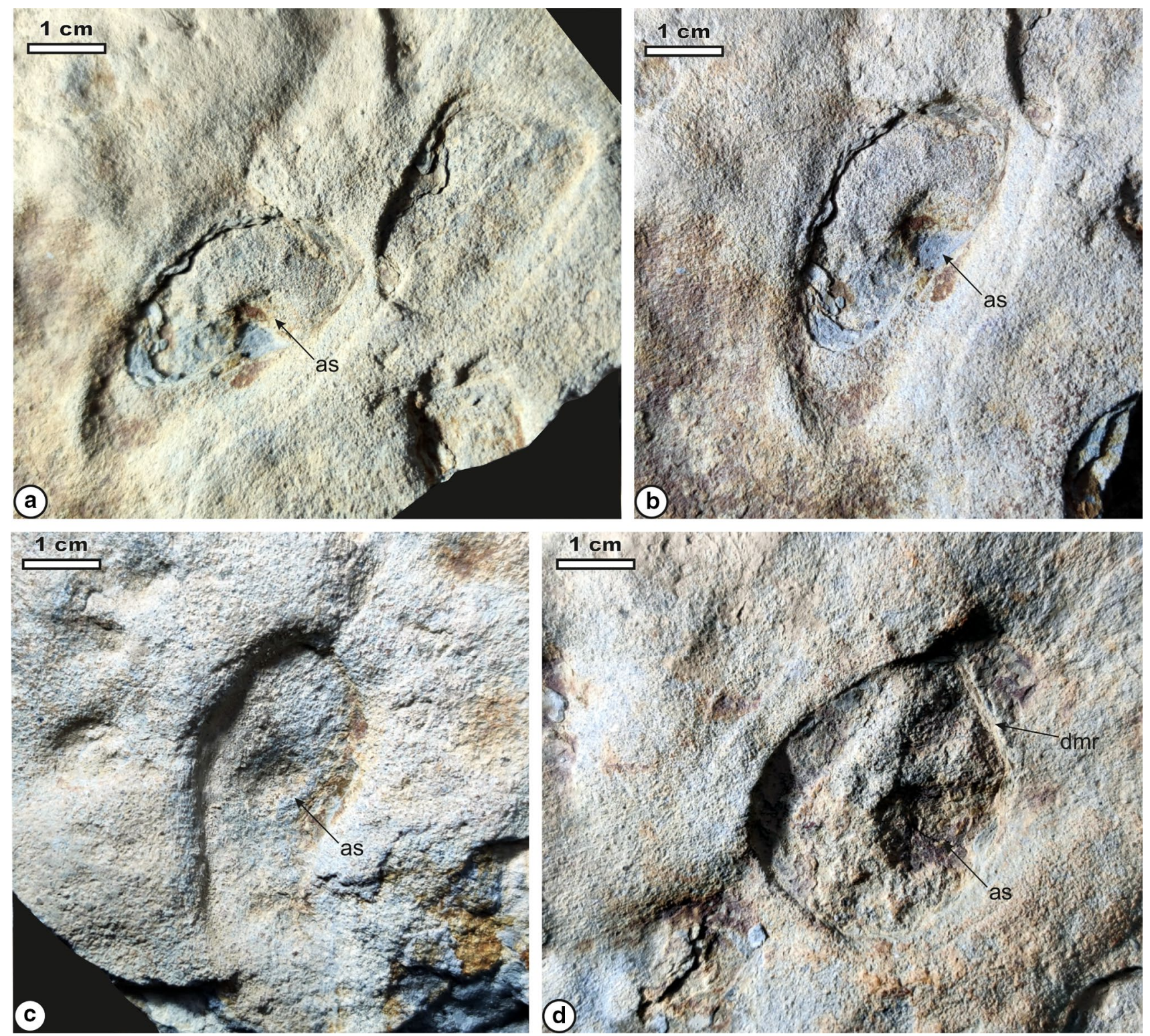

Fig. 6 Other details (a-d) of the large slab from Fig. 4, as atrial syphon, $d m r$ double marginal ridge

The specimen KSU17p215 and KSU17p215/1 (Fig. 10b) shows the same shape as the holotype. It is $95 \mathrm{~mm}$ long, up to $40 \mathrm{~mm}$ wide. Six, more or less complete and an additional one incomplete ridges/grooves are visible. Their course is the same as in the holotype. The edges are sharp and locally elevated. One of the termination is narrower. It forms a dome-like protrusion. The other end is obtuse and seems to partly broken.

The specimen IGKNU17p216 (Fig. 10c, d) is ovate, $38 \mathrm{~mm}$ long, up to $21 \mathrm{~mm}$ wide. It becomes gradually narrower toward its semi-circular distal. The opposite end is obtuse and uneven. The perimeter is located in one third of the length from the obtuse end. Six low ridges and grooves run parallel to the lateral margins of the structure. They disappear toward the ends. A curved tail of small corrugations emerges from the obtuse end (rm in Fig. 10c). Its margins are diffused. Similar corrugations cover larger part of the fossil body.

Remarks. In the holotype, both terminations of the structure touch the edge of the slab, so a possible neck-like protrusion is not visible, if it was present at all. The neck is also not obvious in KSU17p215. The specimen IGKN17p216 is determined as Finkoella cf. oblonga because its ovate shape differs from the elliptical, cucumber-like shape of the holotype. It is also distinctly smaller than the holotype. 

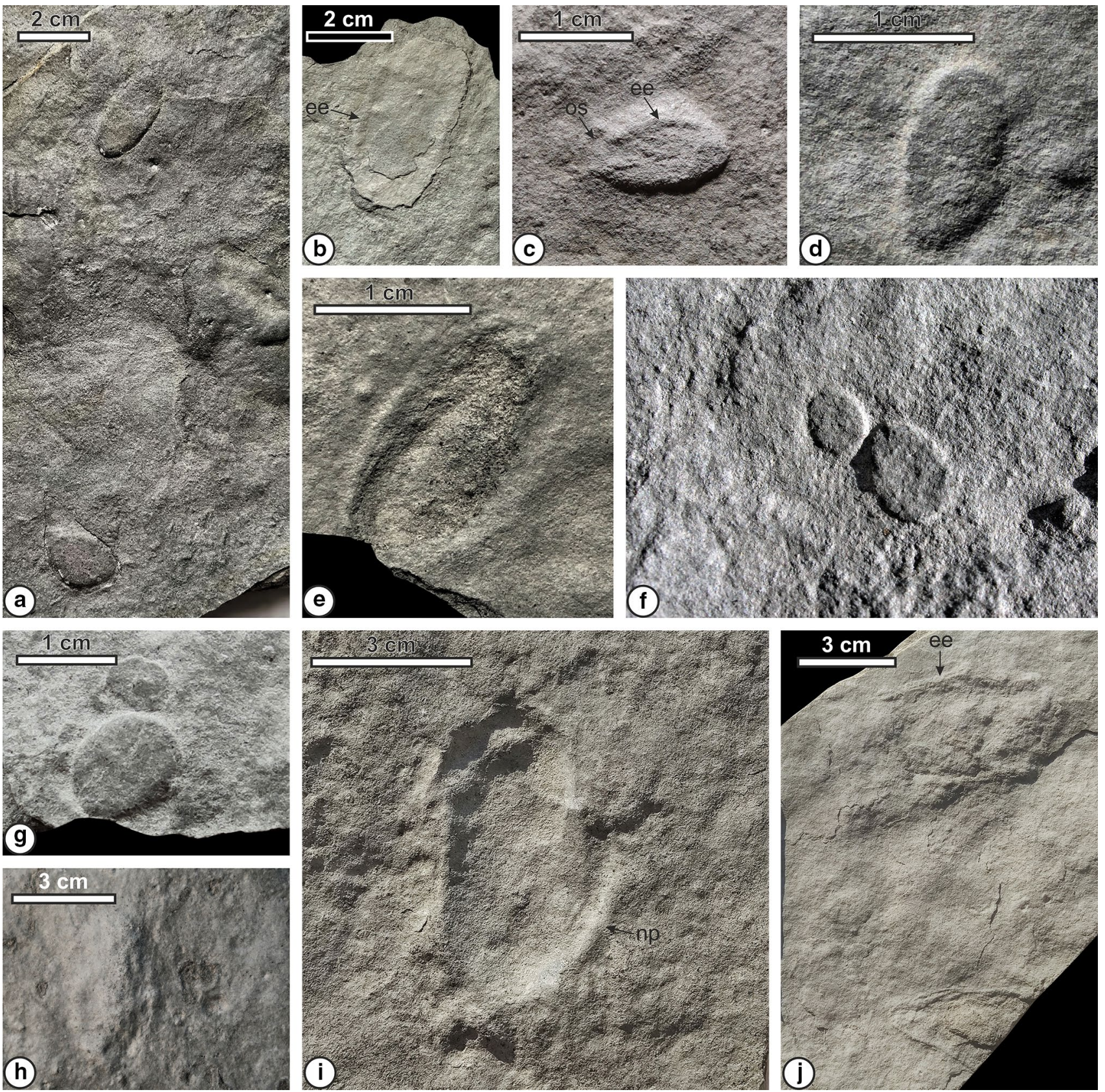

Fig. 7 Other specimens of Finkoella ukrainica from the Lomozov Member of the Mogilev Formation in the quarry near the DHPS, convex hyporeliefs. a Two specimens on slab IGKNU17p204. b IGKNU17p209, ee elevated edge. c IGKNU17p208, elevated edge, os oral syphon. d IGKNU17p205. e Two specimens on

\section{Genus Pharyngomorpha gen. nov.}

Etymology. After the pharyngeal basked, the characteristic anatomic part of tunicates, which is probably preserved in the type species of this genus, and after morpha-in relation to morphology the pharyngeal basked. slab IGKNU17p207. f Slab IGKNU17p205. f Two specimens on slab IGKNU17p210. g IGKNU17p211. h IGKNU17p212. i IGKNU17p213; not the neck-like protrusion (np) on the right side, which is interpreted as the atrial syphon. $\mathbf{j}$ Two specimens on slab IGKNU17p214, ee elevated edge

Type species: Pharyngomorpha reticulata sp. nov.

Diagnosis. Basket-like structures showing ribs and/or grooves arranged in a rectangular net.

Species. Only Pharyngomorpha recticulata-monotypic genus. 
Fig. 8 Plot of width versus length for Finkoella ukrainica

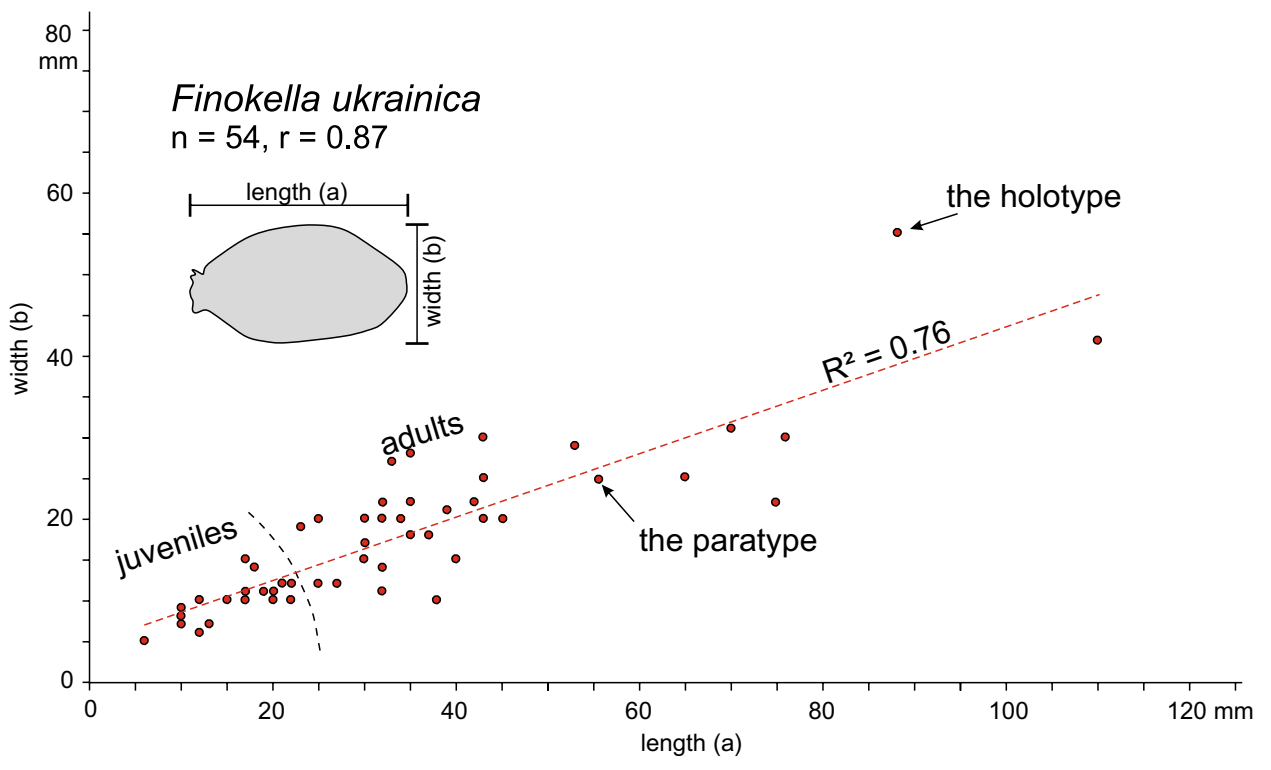

Comparison. No analogues among the Ediacaran and younger fossils.

Distribution. Lomozov Member, Mogilev Formation, Mogilev-Podolsky Group, Upper Ediacaran. Also the lower part of the Nagoryany Formation (Dzhurzhevka Member) in Moldova, dated roughly to 555-551 Ma (Francovschi et al. 2021).

Pharyngomorpha reticulata sp. nov.

Figure 11a-c

2021 ?Ausia/Gibbavasis sponge-like organism-Francovschi et al.: fig. 14E

Etymology. After reticulum (Latin)—net, in correspondence to the morphology.

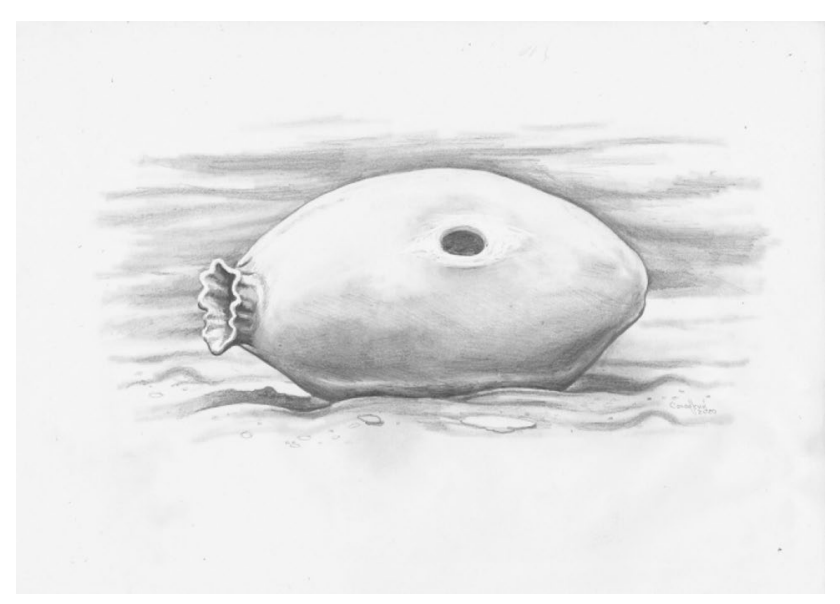

Fig. 9 Reconstruction of Finkoella ukrainica (drawn by S.S. Solodkyi)
Diagnosis. Elongated Finkoella showing winding margins and longitudinal furrows/ridges, which tend to run parallel to the margins.

Holotype. One specimen in the slab IGKNU17p203 (Fig. 11), i.e. IGKNU17p203/1 (Fig. 11b, c) from the Lomozov Member of the Mogilev Formation, Mogilev-Podolsky Group, in the quarry near the DHPS at Bernashivka village, Vinnytsia region.

Description. The holotype is $37 \mathrm{~mm}$ long and up to $19 \mathrm{~mm}$ wide. It contains about ten, straight, perpendicular, densely packed parallel ribs separated by narrow furrows. There is 4 ribs per $10 \mathrm{~mm}$. The furrows are less than $1 \mathrm{~mm}$ wide. The ribs are crossed by five longitudinal furrows (running along the structure) which are perpendicular to the ribs. The longitudinal furrows are c. $1 \mathrm{~mm}$ wide. The ribs in the place of intersection with the longitudinal furrows are still visible but they are much lower than in the inter-ribs stretches. The inter-ribs stretches form rectangles $(5.0 \times 2.5 \mathrm{~mm})$, which are perpendicularly oriented to the structure, so they show the net-like pattern. The structure is elevated in the marginal part. In the narrower part, short bars occur on the margins.

The smaller specimen IGKNU17p203/1 is located c. $20 \mathrm{~mm}$ from the holotype. It is $14 \mathrm{~mm}$ long and $12 \mathrm{~mm}$ wide and composed of five ribs separated by narrow furrows, which are similar to these in the holotype.

Remarks. It is not excluded that the smaller specimen is a disarticulated part of the holotype. In the vicinity of the holotype, poorly outlined ribs can be visible, which may also derive from fragmentation of the organisms represented by the holotype or other individuals. Both specimens 

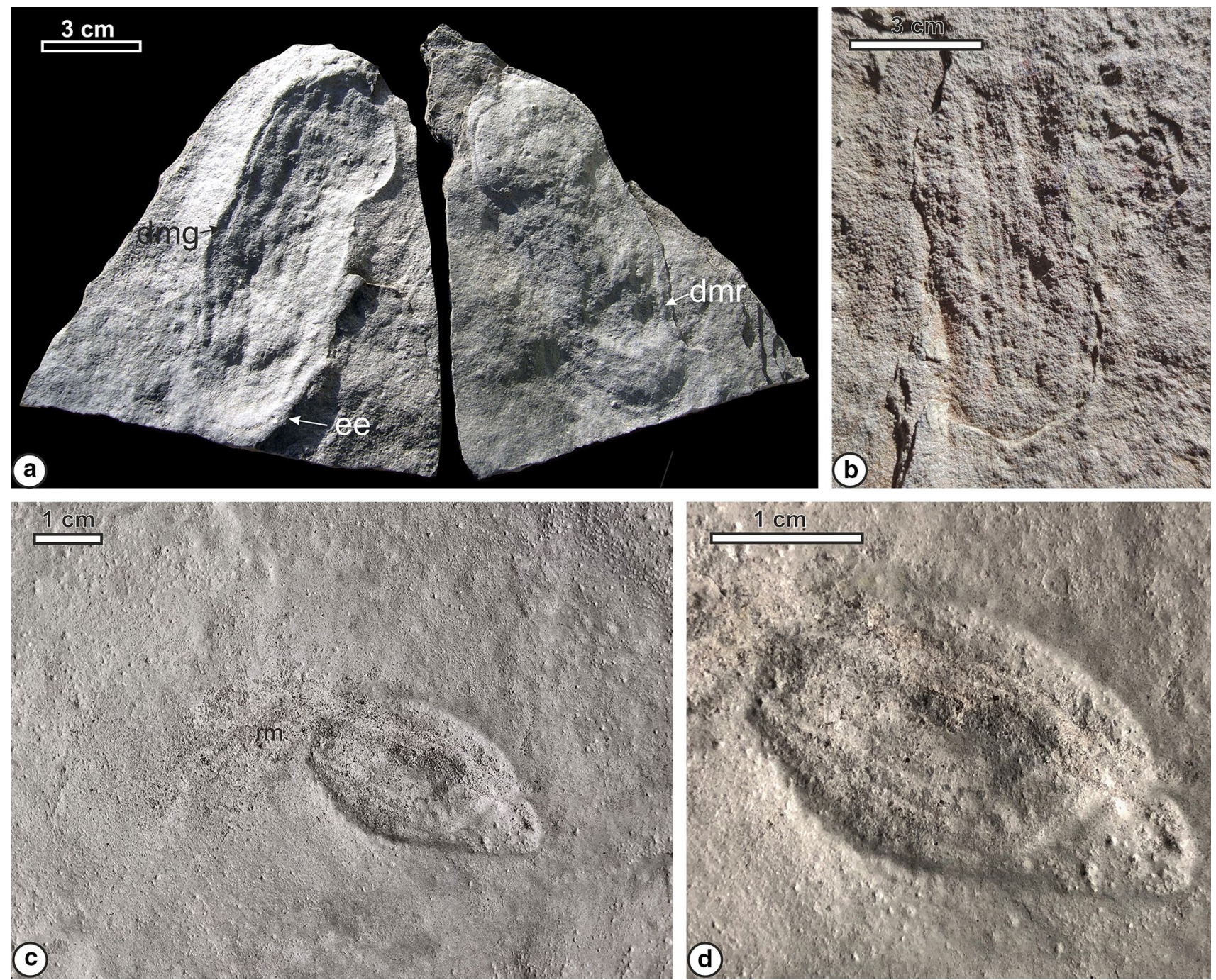

Fig. 10 Finkoella oblonga sp. nov. from the Mogilev Formation in the quarry near the DHPS. a The holotype IGKNU17p202 from the Lomozov Member, $d m g$ double marginal groove, $d m r$ double marginal ridge, ee elevated edge. b. IGKNU17p215, Yampol Member. c
Finkoella cf. oblonga, IGKNU17p216, Lomozov Member, $r m$ realised material (from the body interior). $\mathbf{d}$ Close view of the specimen in $\mathrm{c}$

Ediacaran, Kanilov (Kanyliv) Group, Studenitsa Formation (Komarovo Member), $7 \mathrm{~m}$ below the boundary with the Okunets Formation, ca. $12 \mathrm{~m}$ below the PrecambrianCambrian Boundary. The slab contains Harlaniella on the reverse side.

Description. An incomplete (broken) convex structure having its concave counterpart and an outline of incomplete ellipse, up to $45 \mathrm{~mm}$ wide and at least $42 \mathrm{~mm}$ long (probably twice longer when would be complete). It shows diagonal, straight, narrow furrows, which are about $0.5 \mathrm{~mm}$ wide and 5-8 $\mathrm{mm}$ apart. The furrows show slit-like widenings, up to $4 \mathrm{~mm}$ long and up to $2 \mathrm{~mm}$ wide, $4-5 \mathrm{~m}$ apart, which are deeper than the remaining parts of the furrow. In some 

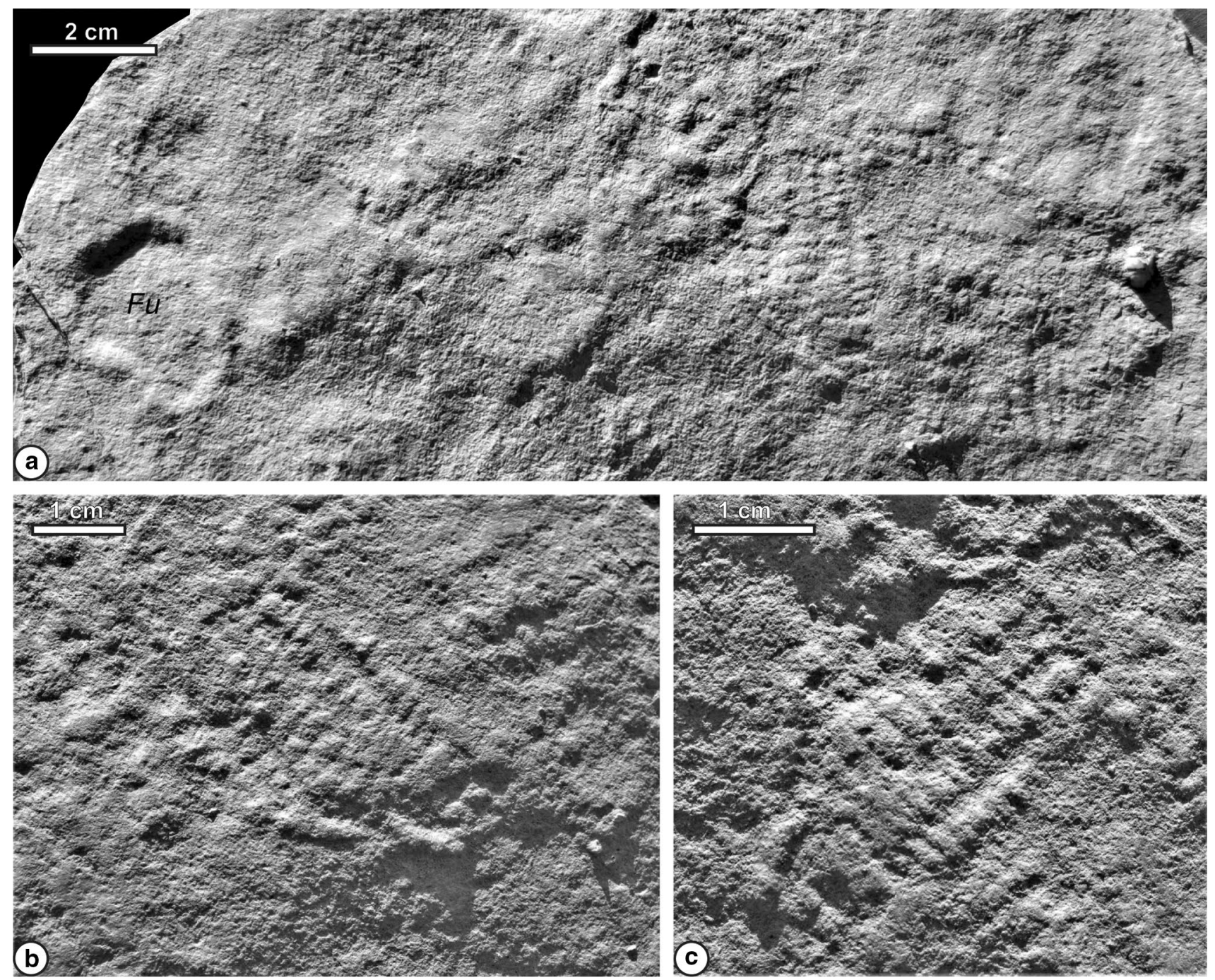

Fig. 11 Pharyngomorpha reticulata sp. nov. from the Lomozov Member of the Mogilev Formation in the quarry near the DHPS. a Two specimens of Pharyngomorpha on the right and Finkoella ukrainica (Fu) on the left, IGKNU17p209. b, c Close views of specimen IGKNU17p209/1

inter-furrow areas, small, oval depressions, 1-2 mm wide may occur. They have a concave counterpart. They are located in the middle between the furrows, in a line parallel to them.

Remarks. Burykhia hunti Fedonkin et al., 2012 (Fig. 11c, d), the only known species of Burykhia is also known from fragments of the pharyngeal basket. However, the pattern of the furrows and depressions and their counterpart is different: it does not show the slit-like depressions along the furrows, and the structures in Burykhia sp. are arranged diagonally, while in $B$. hunti they are transverse and longitudinal.

\section{Discussion}

The morphological features of the described fossils point to animals, which are similar to these of the class Ascidiacea (tunicates). The overall shape of Finkoella resembles sacklike soft body. The neck or sinus at the end of $F$. ukrainica can be interpreted as the oral (branchial, inhalant, incurrent) syphon, while the more regular, circular bulges can be the atrial (exhalent, excurrent) syphon. The elevated edge and the double marginal ridge/groove which are present in some specimens are an evidence of a compressed, elastic sack, which can be interpreted as the tunica. Other irregularities (bulges) on the surface can be manifestations of some internal anatomic elements (heart, stomach, gonads) of the tunicate bulging through the tunic (Fig. 13). Preservation of the syphons may depend on the position of the body during burial. If the syphons are underside the body, they can be 

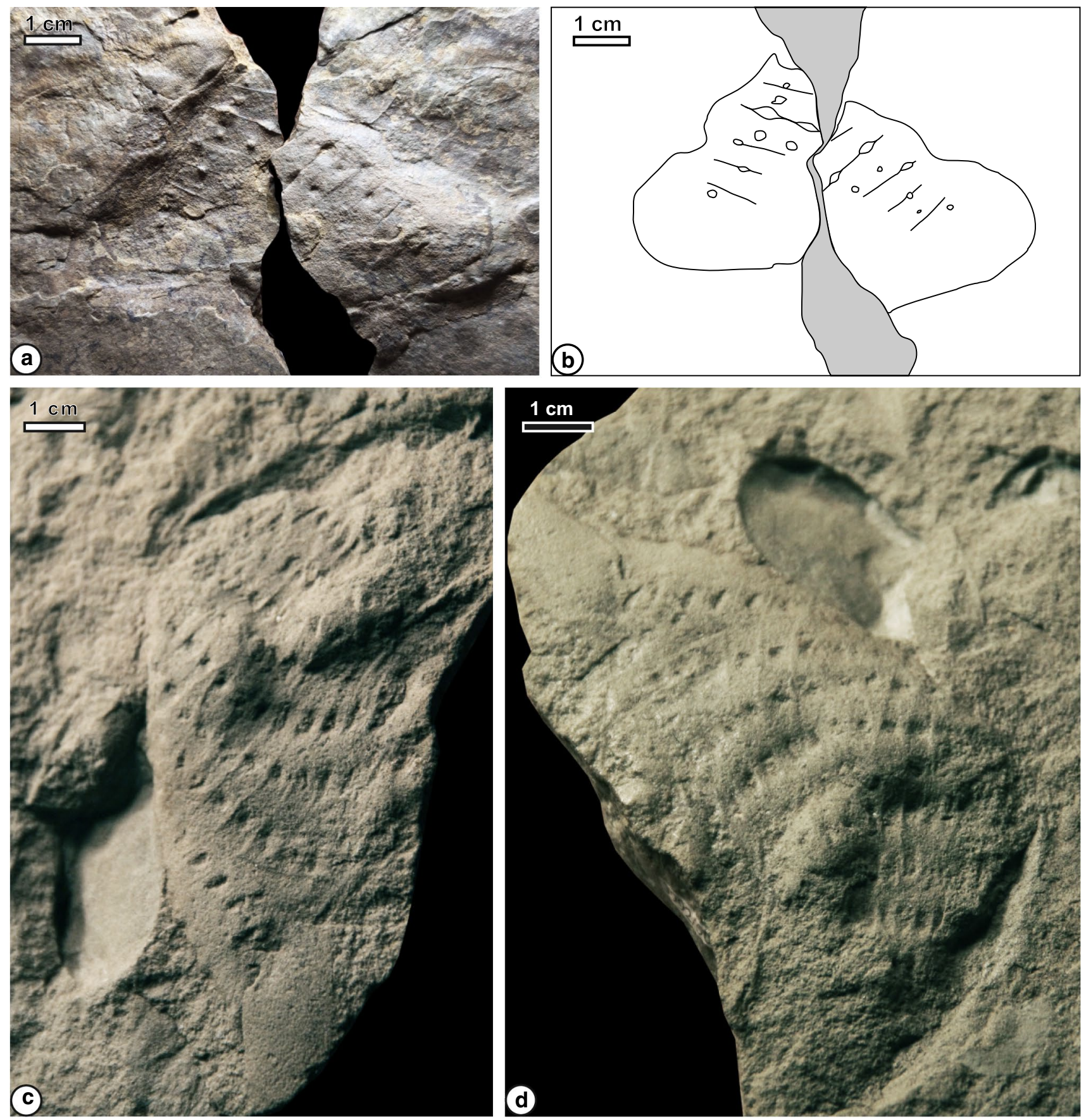

Fig. 12 Burykhia. a Burykhia sp. in mudstone from the Studenitsa Formation at Kitaygorod, IGKNU17p191a (left, upper surface) and b (right, lower surface). b Drawing of A. c, d Burykhia hunti, the type

material (PIN, no. 3992/5048, The Orlov Paleontological Museum of the Paleontological Institute of the Russian Academy of Sciences, Moscow) from the Verkhovka Formation, White Sea coast region

visible only as bulges on the opposite of the body and cannot be clearly recognized.

The smaller specimens of Finkoella ukrainica probably represent juvenile individuals (less than $25 \mathrm{~mm}$ wide by convention; Fig. 8). They prevail in number. Their occurrence in clusters in association with larger, well developed individuals suggest colonial style of life. Such style of life

may result from the asexual reproduction by budding known from some recent ascidians (Holland 2016). This explains the occurrence of numerous juveniles close to small number of adults. However, accumulation by weak currents is not excluded. Distinct orientation of F. ukrainica (Fig. 4b) can result from such currents, which are related to tides, as the 

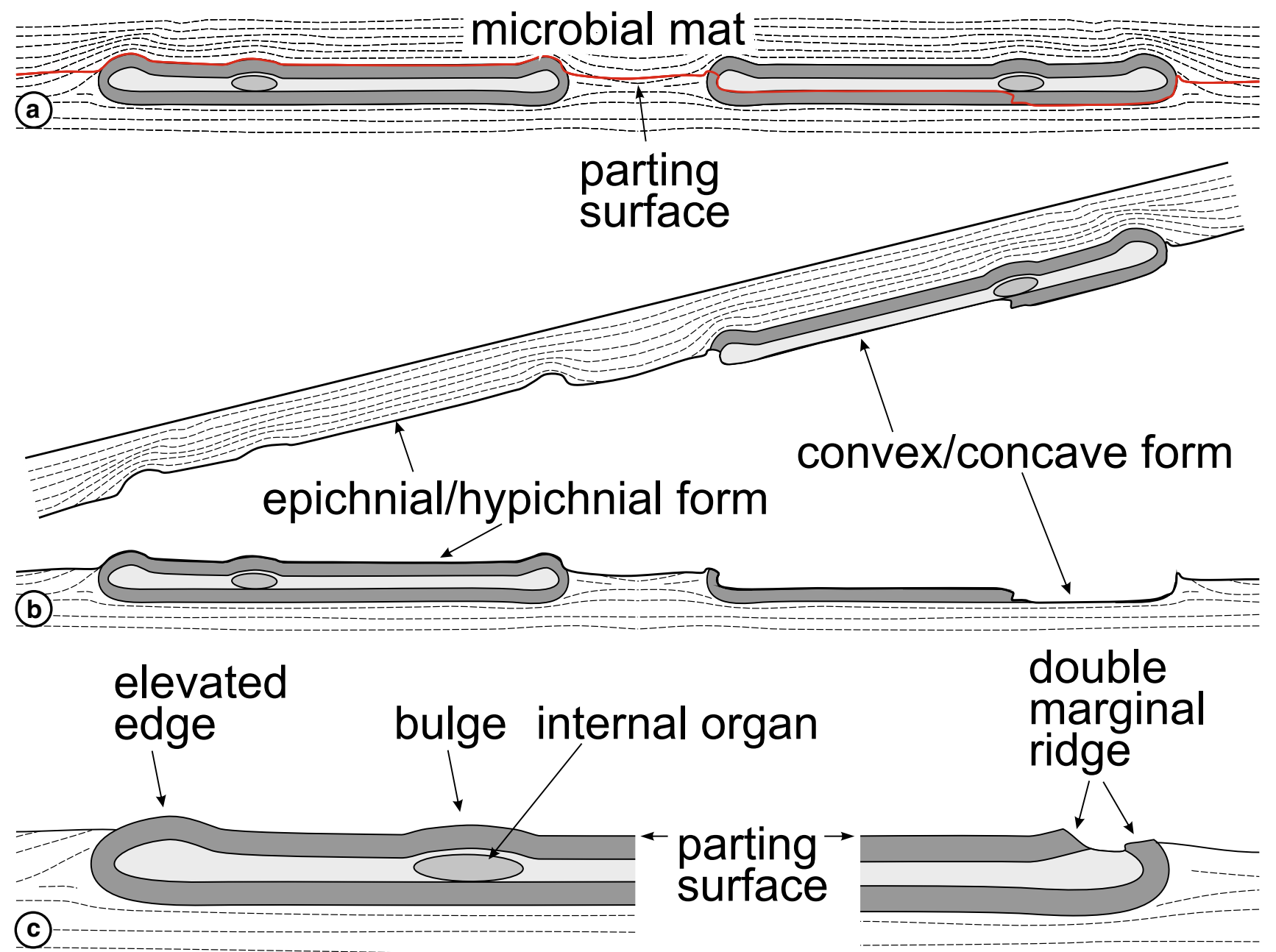

Fig. 13 Preservational mode of preservation of Finkoella. a Formation of "death masks" in between microbial mats with indication of splitting surface. b Appearance on splitting surfaces. c Some morpho-

logical features of Finkoella. The bulge can be formed over an internal organ of the tunicate

intertidal environment is proposed for the rocks bearing the fossils (Uchman and Martyshyn 2020).

Most of the modern tunicates have the standing life position, with their bag-shaped body attached to various hard substrates. However, some tunicates are passively lying on the bottom (Bonnet et al. 2013). It is possible that Finkoella was a tunicate of such type, which is adapted to soft substrates (Fig. 9). This is inferred from the fact that there are no sediment elements that would be hard and no evidence a part of the body which would be attached to such elements or would be anchored in the sediment. Similar mode of life is interpreted to the Ediacaran Yarnemia, which is also tentatively ascribed to tunicates (Chistyakov et al. 1984).

The net-like structure in Pharyngomorpha strongly suggests that it is an imprint or mold of the pharyngeal basket, which is partly similar to the other ascidian Burykhia hunti Fedonkin et al., 2012 from the late Ediacaran deposits

(555 Ma) on the White Sea coast region (Fedonkin et al. 2012). The pharyngeal basket is a characteristic and unique anatomical element of tunicates, where the food particles are trapped in mucus and supplied into the stomach. It shows a sac-like morphology, which may occupy a large part if the body. Its wall is perforated with gill slits and reinforced with ribs. Morphological detail of the basket (arrangements and shape of the gill slits, ribs) may differ among taxa and develop through ontogenetic stages (Lambert 2005; Shenkar and Swalla 2011; Holland 2016). The pharyngeal basket is present in Shankouclava, the oldest reliable tunicate (Chen et al. 2003). Nevertheless, the reticulate anatomical elements, which may resemble the pharyngeal basket can occur in some Ediacaran fossils which ascidian affinity remains controversial, e.g. in Ausia (Hahn and Pflug 1985). Burykhia belongs also to them. The arrangement of slits and ribs in Burykhia points to a 
more complex morphology than simple reticulate from in Pharyngomorpha.

The described Burykhia isp. represents the second occurrence of this genus, which extends its stratigraphic range by about $15 \mathrm{Myr}$ to the latest Ediacaran. Finkoella preserved mostly external part of the body, i.e. tunica, while Burykhia and Pharyngomorpha are probably preserved fragments of the pharyngeal basket. Therefore, Finkoella can be considered as a more completely preserved body of a tunicate.

The changeability of morphology in Finkoella demonstrates dependence on taphonomic factors. These fossils are preserved as probable "death masks" (Gehling 1999) formed my microbes between microbial mats which enveloped the organism after its death (Fig. 13a). Local ferruginization of the surface of the fossils (Figs. 3d, 4a) can derived from the weathered pyrite, which mineralize the body and is common in this type of preservation. Surfaces of the mats and bedding surfaces are the parting surfaces on which the fossils are observed. The concave or convex appearance depends on whether the parting surface propagated below or above to the fossil (Fig. 13b). Therefore, both, convex or concave structures may occur on the same surface as e.g., in the case of slab bearing the holotype (Fig. 3a, b), with their counterparts on the opposite surface, including external molds if the surface runs on the surface of the fossil and the body of the fossil remains on the counterpart surface. If the surface runs through the fossil, its parts can be preserved on both sides. Such cases show that the broken fossil contains at least two layers (Figs. 6a, b, 7b), accordingly to the sack-like morphology.

The presented new taxa along with these which are described so far from the Ediacaran (Ausia, Yarnemia, Burykhia) reinforces the possibility that tunicates originated already in late Ediacaran. As Ausia is no older than $549 \mathrm{Ma}$, Yarnemia than $552 \mathrm{Ma}$ and Burykhia than $555 \mathrm{Ma}$, Finkoella and Pharyngomorpha with their age no younger than $557 \mathrm{Ma}$ can be regarded as the possible oldest representatives of tunicates. In this way, deep roots of vertebrates seem to be more and more probable.

Acknowledgements The authors would like to express their gratitude to S.S. Solodkyi, a devoted participant of field expeditions, who drew the reconstruction of Finkoella ukrainica, and to amateur palaeontologist Sergei Finko who provided the holotype of $F$. ukrainica and the large sandstone slab with the paratype of $F$. ukrainica material for research. A.M. thanks his research supervisor Victor Ogar for helpful discussion and he is also grateful to numerous unnamed assistants in the field research, participants of discussions and consultations. Visit of A.U. in the field was partly supported by the Jagiellonian University. Two anonymous reviewers and Mike Reich, Munich, are acknowledged for critical remarks which helped to improve the paper.

Open Access This article is licensed under a Creative Commons Attribution 4.0 International License, which permits use, sharing, adaptation, distribution and reproduction in any medium or format, as long as you give appropriate credit to the original author(s) and the source, provide a link to the Creative Commons licence, and indicate if changes were made. The images or other third party material in this article are included in the article's Creative Commons licence, unless indicated otherwise in a credit line to the material. If material is not included in the article's Creative Commons licence and your intended use is not permitted by statutory regulation or exceeds the permitted use, you will need to obtain permission directly from the copyright holder. To view a copy of this licence, visit http://creativecommons.org/licenses/by/4.0/.

\section{References}

Blainville, H.M.D. de. 1824. Mollusques, Mollusca (Malacoz.). In Dictionnaire des Sciences Naturelles, vol. 32, ed. F. Cuvier, 1-392. Paris: Le Normant.

Bonnet, N.Y.K., R.M. Rocha, and M.R. Carman. 2013. Ascidiidae Herdman 1882 (Tunicata: Ascidiacea) on the Pacific coast of Panama. Zootaxa 3691(3): 351-364. https://doi.org/10.11646/ zootaxa.3691.3.4.

Chen, J.-Y., D.-Y. Huang, Q.-Q. Peng, H.-M. Chi, X.-Q. Wang, and M. Feng. 2003. The first tunicate from the Early Cambrian of South China. Proceedings of the National Academy of Sciences 100: 8314-8318. https://doi.org/10.1073/pnas.1431177100.

Chistyakov, V.G., N.A. Kalmykova, L.A. Nesov, and G.A. Suslov. 1984. O nalichii vendskikh otlozheniy v srednem techeni $\mathrm{r}$. Onegi i vozmozhnosti sushchestovani obolochechnikov (Tunicata: Chordata) v dokembri [On the presence of Vendian deposits in the middle course of the Onega River and presumable existence of tunicates (Tunicata: Chordata) in Precambrian]. Vestnik Leningradskogo Gosudarstvennogo Universiteta (LGU) 6: 11-19. (in Russian).

Dzik, J., and A. Martyshyn. 2015. Taphonomy of the Ediacaran Podolimirus and associated dipleurozoans from the Vendian of Ukraine. Precambrian Research 269: 139-146. https://doi.org/ 10.1007/s10347-010-0248-7.

Dzik, J., and A. Martyshyn. 2017. Hydraulic sediment penetration and seasonal growth of petalonamean basal discs from the Vendian of Ukraine. Precambrian Research 302: 140-149. https://doi.org/10. 1016/j.precamres.2017.09.024.

Fedonkin, M.A. 1985. Sistematicheskoye opisanie vendskikh Metazoa. In Vendskaya Sistema. Istoriko-geologicheskoye i paleontologicheskoye obosnovanie 1, eds. B.S. Sokolov and M.A. Fedonkin, 70-106. Moskva: Nauka. (in Russian).

Fedonkin, M.A., and P. Vickers-Rich. 2007. Podolia's green valleys. In The rise of animals: evolution and diversification of the kingdom animalia, eds. M.A. Fedonkin, J.G. Gehling, K. Grey, G.M. Narbonne, and P. Vickers-Rich, 149-155. Baltimore: Johns Hopkins University Press.

Fedonkin, M.A., P. Vickers-Rich, B.J. Swalla, P. Trusler, and M. Hall. 2012. A new metazoan from the Vendian of the White Sea, Russia, with possible affinities to the ascidians. Paleontological Journal 46: 1-11. https://doi.org/10.1134/S0031030112010042.

Francovschi, I., E. Grădinaru, H. Li, L. Shumlyanskyy, and V. Ciobotaru. 2021. U-Pb geochronology and $\mathrm{Hf}$ isotope systematics of detrital zircon from the late Ediacaran Kalyus Beds (East European Platform): Palaeogeographic evolution of southwestern Baltica and constraints on the Ediacaran biota. Precambrian Research 355: 106062. https://doi.org/10.1016/j.precamres.2020.106062.

Gehling, J.G. 1999. Microbial mats in terminal Proterozoic siliciclastics: Ediacaran death masks. Palaios 14: 40-57. https://doi.org/ $10.2307 / 3515360$ 
Gnilovskaya, M.B. 1971. Most ancient water plants of Vendian of Russian platform (Late Precambrian). Paleontologicheskiy Journal 1971(3): 101-107. (in Russian).

Gozhik, P.F. (ed.) 2013. Stratyhrafija verkhn'oho proterozoyu ta fanerozoyu Ukrayiny: u. 2 t. 1: Stratyhrafija verkhn'oho proterozoyu, paleozoyu ta mezozoyu Ukrayiny [Stratigraphy of the Upper Proterozoic and Phanerozoic of Ukraine: $u .2$ vol. 1: Stratigraphy of the Upper Proterozoic, Palaeozoic and Mesozoic of Ukraine], 1-637. Kyiv: Logos (Institute of Geological Sciences of the National Academy of Sciences of Ukraine). (in Ukrainian).

Grazhdankin, D.V. 2011. Chronostratigraphia verkhneho venda (na primere razrezov sever-vostochnoy okrainy Vostochno-Evropeiskoy platform i zapadnogho sklona Srednego Urala. Doctoral Thesis, Institut Neftegazovoy Geologi i Geofiziki im. Trofimiuka Sibirskogho Otdelenia Rossiyskoy Academii Nauk, Novosibirsk, 1-313. (in Russian).

Grazhdankin, D.V. 2014. Patterns of evolution of the Ediacaran softbodied biota. Journal of Paleontology 88: 269-283.

Grazhdankin, D.V., and A.V. Maslov. 2015. The room for the Vendian in the International Chronostratigraphic Chart. Russian Geology and Geophysics 56: 549-559.

Grazhdankin, D.V., V.V. Marusin, J. Meert, M.T. Krupenin, and A.V. Maslov. 2011. Kotlin regional stage in the South Urals. Doklady Earth Sciences 440: 201-206.

Grytsenko, V. 2020. Diversity of the Vendian fossils of Podillia (Western Ukraine). GEO\&BIO 19: 3-19.

Gureev, Y.A. 1983. Kiltzovye bioglifi iz otlozheniya kalinovskoi serii venda pridniestrivia. Geologicheskii Zhurnal 43: 130-132. (in Russian).

Gureev, Y.A. 1984. Bioglify fanerozoiskoho oblika v viendie Podolii i ich stratigraficheskoye znachenie. Doklady Academii Nauk Ukrainskoy SSR (Seria B) 4: 5-9. (in Russian).

Gureev, Y.A. 1986. O perspektivakh paleoichnologitcheskogo metoda v stratigrafii. Tektonika i Stratigrafia 27: 42-47. (in Russian).

Hahn, G., and H.D. Pflug. 1985. Polypenartige Organismen aus dem Jung-Präkambrium (Nama-Gruppe) von Namibia. Geologica et Palaeontologica 19: 1-13.

Herdman, W A. 1882. Report on the Tunicata collected during the voyage of H.M.S. Challenger during the years 1873-1876. Part 1, Ascidiae simplices. Report on the Scientific Results of the Voyage of H.M.S. Challenger during the years 1873-76. Zoology 6(17): $1-296$.

Holland, L.Z. 2016. Tunicates. Current Biology 26: R146-R152.

Ivantsov, A.Y., V.P. Gritsenko, V.M. Paliy, A.S. Menasova, M.A. Fedonkin, M.A. Zakrevskaya, and E.A. Serezhnikova. 2015. Atlas of macrofossils from Upper Vendian and Lower Cambrian of Middle Dniester area and Volhyni. In Upper Vendian Macrofossils of Eastern Europe. Middle Dniester Area and Volhynia, eds. A.Y. Ivantsov, V.P. Gritsenko, V.M. Paliy, V.A. Velikanov, L.I. Konstantinenko, A.S. Menasova, M.A. Fedonkin, M.A. Zakrevskaya, and E.A. Serezhnikova, 92-143. Moscow: Russian Academy of Sciences, Borissiak Palaeontological Institute.
Korenchuk, L.W., and A.A. Ishchenko. 1981. Sedimentatsionnaya tsyklichnost vendtskikh odlozheniy Pridnestrovia, 1-56. Kiev: Akademia Nauk Ukrainy, Institut Geologicheskikh Nauk. (in Russian).

Lamarck, J.-B.M. de. 1816. Histoire naturelle des animaux sans vertèbres. Tome second, 1-568. Paris: Verdière.

Lambert, G. 2005. Ecology and natural history of the protochordates. Canadian Journal of Zoology 83: 34-50. https://doi.org/10.1139/ z04-156.

Martyshyn, A. 2012. Ediakarska fauna yampilskikh piskovikiv vendu Podillya. Geologia Ukrainy 2012(4): 97-103. (in Ukrainian).

Nesterovsky, V.A., A.I. Martyshyn, and A.M. Chupryna. 2018. New biocenosis model of Vendian (Ediacaran) sedimentation basin of Podolia (Ukraine). Journal of Geology, Geography and Geoecology 27: 95-107. https://doi.org/10.15421/111835.

Palij, V.M. 1974. Bilobate traces of locomotion from the deposits of the Baltic Group in the Dniester Region. Doklady Akademii Nauk Ukrainskoy SSR (Seria B) 1974: 499-503. (in Ukrainian).

Palij, V.M. 1976. Ostatki besskeletnoi fauny i sledy zhiznedeiatelnosti iz otlozhenii verkhnego dokembria i nizhnego kembria Podolii [Remains of soft bodied fauna and trace fossils from Upper Precambrian and Lower Cambrian deposits in Podolia]. In Paleontologiia i stratigrafiia verkhnego dokembria i nizhnego paleozoia iugo-zapada Vostochno-Evropeiskoi platformy [Remains of nonskeletal fauna and traces of life from deposits of the Upper Precambrian and Lower Cambrian of Podolia], ed. P.L. Shulga, 63-77. Kiev: Naukova dumka. (in Russian).

Poprawa, P., N. Radkovets, and J. Rauball. 2018. Ediacaran-Paleozoic subsidence history of the Volyn-Podillya-Moldavia basin (W and SW Ukraine, Moldova, NE Romania). Geological Quarterly 62: 459-486. https://doi.org/10.7306/gq.1418.

Seilacher, A. 1955. Spuren und Fazies im Unterkambrium. In Beiträge zur Kenntnis des Kambriums in der Salt Range (Pakistan), eds. O.H. Schindewolf, and A. Seilacher. Akademie der Wissenschaften und der Literatur in Mainz, Abhandlungen der mathematischnaturwissenschaftlichen Klasse 10: 373-399.

Shenkar, N., and B. Swalla. 2011. Global diversity of Ascidiacea. PLoS One 6(6): 1-12. https://doi.org/10.1371/journal.pone.00206 57.

Soldatenko, Y., A. El Albani, M. Ruzina, C. Fontaine, V. Nesterovsky, J.-L. Paquette, A. Meunier, and M. Ovtcharova. 2019. Precise $\mathrm{U}-\mathrm{Pb}$ age constrains on the Ediacaran biota in Podolia, East European Platform, Ukraine. Nature Scientific Reports 9(1675): 1-13. https://doi.org/10.1038/s41598-018-38448-9.

Uchman, A., and A. Martyshyn. 2020. Taxis behavior of burrowing organisms recorded in an Ediacaran trace fossil from Ukraine. Palaeogeography, Palaeoclimatology, Palaeoecology 538: 109441. https://doi.org/10.1016/j.palaeo.2019.109441.

Velikanov, V.A. 1985. Opornyi razrez venda Podolii. In Istoriko-geologicheskoye i paleontologicheskoye obosnovanie 2. Vendskaya Sistema, eds. A.B. Ivanovskiy and B.S. Sokolov, 35-66. Moskva: Nauka. (in Russian). 